\title{
Taking Socialist Core Values to Guide the Voluntary Service with Chinese Characteristics
}

\author{
Wu Liansong \\ School of Foreign Studies, Yangtze University, Jingzhou, China
}

Email address:

wls@mails.ccnu.edu.cn

To cite this article:

Wu Liansong. Taking Socialist Core Values to Guide the Voluntary Service with Chinese Characteristics. Advances in Sciences and Humanities. Vol. 3, No. 1, 2017, pp. 1-4. doi: 10.11648/j.ash.20170301.11

Received: March 11, 2017; Accepted: April 14, 2017; Published: April 26, 2017

\begin{abstract}
Volunteer service is a critical symbol of modern civilization as well as an important channel and way to cultivate and practice the socialist core values, the spirit of volunteerism it advocates is the organic combination of the traditional virtues of Chinese nation and the spirit of the era of reform and innovation in China. It has intrinsic unity with socialist core values. To construct of the volunteer service spirit with Chinese characteristics, we must continue to play the leading role of the socialist core values, attract and appeal more people to participate in volunteer service, and promote the harmonious and orderly development of volunteer service.
\end{abstract}

Keywords: Voluntary Service, Socialist Core Values, Internal Consistency

\section{Introduction}

Since the Eighteenth National Congress of the Communist Party of China, voluntary service has become a trend and fashion, and plenty of voluntary service groups emerged just like bamboo shoots after a spring rain. Voluntary service and the volunteer spirit it advocated, i.e. dedication, friendship, mutual assistance and progress have lodged themselves in the public mind. The socialist core values are the most profound spiritual core of the socialist core value system. To guide social trends of thought and forge public consensus with socialist core values, we must internalized the socialist core values in the heart and externalized it to the behaviors. Voluntary Service will achieve the unity of self-worth and social value, which is the important channel to the implementation of socialist core values.

\section{Volunteer Service and Its Educational Functions}

The volunteer service is anyone who is willing to contribute his/her time and energy, without material reward, and provides services to promote human development, social progress and social welfare [1]. As one of the most favorite social practice activities of college students, volunteer service is an important way for college students to participate in social life, realize self-education and self-worth. It has become an effective carrier under the new situation of ideological and political education of college students, and plays an active role in promoting students' growth and accomplishment, the educational functions of which are mainly in the following areas.

\subsection{To Help College Students to Foster Correct World Outlook, Outlook on Life and Values}

The university stage is the crucial period of fostering world outlook, outlook on life and values for college students. During the formation of social transformation, affected by money worship, hedonism and individualism, value system of college students are subjected to a great challenge. Volunteer service is both "helping others" and "self-help", satisfy others as well as please oneself [2]. It enables students to deepen their understanding of the country and society, the practice process of which contains affluent educational contents of Ideology and morality. Roses given, fragrance in hand. That is to say helping others will benefit yourself as well. Volunteer service integrate ideological cultivation theories into practice. And long-term volunteer service can help students cultivate favorable moral consciousness, and play a positive guiding role to their ideological values, which is conducive to the formation of their correct world outlook, outlook on life and 
values.

\subsection{To Strengthen Students' Sense of Social Responsibility and Improve Their Overall Quality}

Social responsibility is the direct embodiment of the quality of college students. In the background of economic globalization and diversification of ideology, the social responsibility of college students will affect the harmonious and healthy development of the socialist cause [3]. Through volunteer services, students dedicate themselves to social welfare, and their consciousness of the society have been enhanced, which cultivate their personality of assume responsibility for themselves, their family and the society. In this sense, volunteer service plays an important role in promoting their unity of knowledge and behavior and fostering healthy sense of social responsibility. At the same time, participating in the organization and management of volunteer service, tackling kinds of complex problems they faced provide a significant manner to improve the college students' team consciousness, responsibility consciousness, practical ability and problem-solving ability, and other comprehensive quality effectively.

\subsection{To Cultivate College Students' Practical Ability and Promote the Formation of Positive Campus Culture}

Owning to the restrictions of subjective and objective conditions, post-95s College students always attach much attention on the book and underestimate the role of the practice, their abilities of interpersonal communication and independent judgment is relatively weak [4]. Through volunteer service activities, college students' abilities of organization, coordination, expression, practice have been improved rapidly, which is beneficial to the future study, employment, entrepreneurship. In addition, volunteer service activities also greatly enrich the spiritual and cultural life of college students, the spirit of the volunteers has become a beautiful scenery line in campus. Volunteers dedicate themselves to serve the community as a tireless pursuit, the spirit of which not only help promote the mainstream values of the campus culture, but also contribute to the formation of the positive campus culture.

\section{The Inherent Consistency of the Spirit of Volunteerism and Socialist Core Values}

Volunteerism, in the final analysis, a public spirit that is voluntary, based on some moral conscience or some thought of expecting no return, is a vital form for public to participate in social life [5]. As the deepest spiritual core of socialist core value system, socialist core values owns strong appeal, influence and cohesion.

Marx once pointed out that "Social life is essentially practical." To cultivate and practice of socialist core values, it must be based on the practice of socialism with Chinese characteristics, and continue to play a role of socialist core values in leading social thought, fostering social consensus, and promoting social progress, and demonstrate its greater spiritual strength. The spirit of volunteer service embodies the connotation of the socialist core value system, which is the micro reflection of the socialist core values, in this sense, they are inherent consistency each other. This paper will discuss the consistency of the two from the following perspectives.

\subsection{The Basic Connotation and Fundamental Requirements of Voluntary Service and Socialist Core Values Are Consistent.}

Marxist philosophy holds that the value is a category that reflects the relationship between subject and object. The value of education is to satisfy the demand of education subject which is offered by the attribute or function of education object. Values are the fundamental point of view about what value is, how to judge the value and how to create the value of such issues. Core values is in the leading and dominant status. Socialist core values are those values that are dominant in the socialist system, and play a decisive role in guiding values, with the values of the socialist system is the most basic part of the core [6].

Conforming to the development of Chinese contemporary social needs and common aspirations of the masses, the Eighteenth National Congress of the Communist Party of China put forth the "socialist core values". It clearly stated that "promoting prosperity, democracy, civility, and harmony, upholding freedom, equality, justice and the rule of law and advocating patriotism, dedication, integrity, and friendship, so as to cultivate and observe core socialist values." From three different levels, the socialist core values regulate the pursuit of the core values of our country, society and citizens [7].

The basic connotation and basic requirements of voluntary service coincide with the socialist core values, mainly reflected on the followings: First, the "dedication, friendship, mutual aid, and progress" volunteer spirit reflects the lofty ideals and firm convictions of patriotism, and reflect the fundamental requirement of socialist core values. Secondly, as an important spiritual factor, voluntary service not only promote the building of socialist harmonious society and the construction of socialist spiritual civilization, but also pass by the faith of "friendliness". Thirdly, advocating dedication, friendship and mutual assistance and common progress, Volunteerism is coincide with the basic connotation and fundamental requirements of the socialist core values, which is the proper meaning of the practice of the socialist core values.

\subsection{Volunteerism Is the Combination of National Spirit and the Spirit of the Times}

The national spirit is the spiritual support of a nation's survival and development, and is also the core of a nation's vitality, creativity and cohesion. In the five thousand years course of development of the Chinese nation, it has formed the great national spirit with patriotism as the core, unity, peace loving, hardworking and brave as the main embodiment. Formed and developed in the new historical conditions, the 
spirit of the times is the sum of the embodiment of national characteristics, trend of thought, behavior, value orientation, spirit and social morality. In the current conditions, reform and innovation is the core of the national spirit of the times.

The essence of socialist core values is the national spirit with patriotism as its core and the spirit of the times with reform and innovation as its core. As a spiritual force, volunteerism focuses on the needs of others. It has consistency with Chinese traditional virtues of helping the trapped, the social responsibility that volunteer service assumed is the direct and realistic embodiment of patriotism. The formation and development of voluntary service has distinctive contemporary characteristics. Volunteer spirit is the organic combination of Chinese traditional virtue and the reform and innovation of the spirit of the times, and is the embodiment and promotion of the essence of socialism in the new era [8], which not only promote the social harmony and progress, but also enrich and develop the connotation of reform and innovation the spirit of the times.

\subsection{The Volunteer Spirit Is the Specific Interpretation of the Concept of Serving the People Wholeheartedly of the Socialist Core Values}

Since the reform and opening up policy implemented in 1978 in China, Marx's ideology is still dominant, but it is affected seriously by the value theory of pluralism, and the values of some social groups are even distorted, which has made a serious impact on the values of socialism. The essence of socialist core values is to serve the people heart and soul. Serving the people heart and soul is the fundamental purpose of the Communist Party of China, and is also the foundation of the long-term ruling of the Communist Party of China.

The volunteer spirit is the concrete practice and vivid reflection of serving the people wholeheartedly. Through the helping of the elderly, financially strapped families, disabled and needy students, students can make acquaintance with their daily needs, and solve their practical difficulties in their lives, as a result, the needy and inconvenient group can get warmth from the society in a positive way, which is helpful to build a harmonious society. The spirit of "friendship and mutual assistance" that students reflected on the process of voluntary service is a concrete manifestation of socialist collective thoughts; the spirit of "dedication and mutual progress" can promote the coordinated development and common progress in all areas of society.

Therefore, serving the people wholeheartedly is the core and soul of the socialist core values. Cultivating and practice the socialist core values should highlight the idea of serving the people, which is highly consistent with the spirit of voluntary service.

\subsection{Voluntary Service Is an Important Channel and Way of the Practice of Socialist Core Values}

To cultivate and practice the socialist core values, we must insist on a combination of knowing and doing, persist in that actions speak louder than words, and pay much attention to promote the socialist core values into the pursuit of the spirit and to turn the spirit into practical action. The process of participating in volunteer service is the process to identify the basic norms of citizen morality, i.e. comprehending the great virtue, keeping morality and being strict in private morality, in the positive culture atmosphere for students. It is also the process of amendment, formation and unity in the understanding of values while in their interaction of thinking and behavior.

As an important subject to cultivate and practice the socialist core values, we must make sure students can play the main role in practicing the socialist core values, and guide them to participate in voluntary service actively. Through the public actions like giving help to the orphans, the elderly, the young and other needy groups, correct concept of practice and values can be established in a right way, which is conducive to achieve self-education, self-improvement and self-perfection for the students.

\section{To Guide the Voluntary Service with Chinese Characteristics with Socialist Core Values}

Voluntary service is one of the appropriate ways to distribute warmth to needy groups, to make human accept the feelings of warmth, and to make the society become homely.

The socialist core values are the practical needs of the construction of socialist culture with Chinese characteristics, and it is the action program to guide the ideological and political education of college students. Leading the volunteer service with the socialist core values, we can proceed from the following aspects.

\subsection{With the Guidance of the Socialist Core Values, to Help College Students Establish Correct World Outlook, Outlook on Life and Values}

Voluntary service is an important way to transform the socialist core values into faith [9]. To understand the connotation of socialist core values correctly will not only benefit to the long-term stable development of the national society, but also has great significance in the formation of values and outlook on life. The socialist core values have formed a huge value consensus and ideological resonance in the whole society and created a good social atmosphere for volunteer service activities, which play a positive role in promoting the formation of the correct world outlook, outlook on life and values for students.

\subsection{With the Guidance of the Socialist Core Values, to Cultivate Patriotism, Professionalism, Integrity, Quality and Friendly Character for College Students}

The socialist core values can be divided into three levels of state, society and individuals, from the national level of "prosperity, democracy, civilization and harmony", it aims at cultivating college Students' patriotic consciousness, and 
inspiring them to set ambitious goals; From the social level of "freedom, equality, justice, rule of law", it emphasizes the combination of the students' social and individual value, and inspires the students to realize their personal value in the dedication. From the individual level of "patriotism, dedication, integrity, kindness", it emphasizes the students should abide by the moral bottom line, promote the consciousness of inheritance of Chinese traditional culture in the voluntary practice, strengthen self-discipline, and improve personal accomplishment, as a result, to become a thoughtful and moral students consciously.

\subsection{With the Guidance of the Socialist Core Values, to Play a Crucial Role in Promoting the All-Round Development of College Students}

Marx's epistemology pointed out that practice is the sole criterion for testing truth. Practice is not only the basis of the formation and development of the core values of socialism, but also the only standard to testify the effectiveness and efficiency of the cultivation and practice of socialist core values for college students [10]. Volunteer service is an important carrier for college students to participate in social practice. To play the leading role of the socialist core values, we must attach great importance to the practice of volunteer service, encourage they improve the overall quality in organization, management, planning, interpersonal communication, discovering and solving problems and issues on the basis of their professional characteristics and personal skill, and achieve the goal of putting virtue in the first place, possessing both political integrity and ability and all-round development.

\section{Conclusion}

In conclusion, volunteer service is an effective carrier of cultivating and practicing socialist core values for college students, and an important platform to turn the socialist core values into spiritual beliefs. Volunteer service spirit and the socialist core values are consistent with each other, and interactive relationship has been formulated. The construction of socialist core values provides a strong institutional guarantee for the healthy development of voluntary service, and the increasing development of voluntary service is the important way to build the core values of socialism. To effectively develop the leading role of the socialist core values, we must promote the voluntary service work in a harmonious and orderly way.

\section{Acknowledgements}

This paper is the findings of the research project of "Cultivation and Practice of College Students' Socialist Core Values from the Perspective of Volunteer Service (No. 2015GB044)", Hubei Province educational and scientific planning project in 2015, of the Party Building Scientific Project in 2015 "The Role of College Students' Volunteer Service Activities in the Party Building and Ideological and Political Education" AND of the Social Science Fund Project "Study on the Effect of Voluntary Service in Constructing the Socialist Core Values (No. 2015B02)" Supported by Yangtze University.

\section{References}

[1] Zhang S. 2012. Investigation and Study on College Students' Volunteer Service-- Taking Nanjing University of Information Science and Technology as an Example [J]. Front 16: 16-18.

[2] Wu L. S. 2017. Taking Volunteer Service as a Carrier to Enhance the Socialist Core Values of College Student's Identity Path Construction [J]. Beijing Youth Research 84:83-88.

[3] Li Y. 2015. On the Cultivation of College Students' Socialist Core Values Based on Volunteer Service [J]. Yangzhou University (Higher Education Study Edition) 59:58-61.

[4] Jiang C. B., Ren J. X. 2016. Volunteer Service: the Effective Carrier of College Students Practicing Socialist Core Values [J] Journal of Ideological \& Theoretical Education 108:107-110.

[5] Yang J., Han Z. X. 2015. On the Cultivation of College Students' Socialist Core Values from the Perspective of Volunteer Service [J]. School Party Building and Ideological Education 9:9-11.

[6] Ji C. Y, Huang P. 2010. Volunteer Service and the Cultivation of College Students' Core Values [J]. People's Forum 228:228-229.

[7] Qiu Q. Y, Li Y. F. 2013. On the Cultivation of College Students' Socialist Core Values--based on Volunteer Service Activities [J]. Journal of Changchun University of Technology (Higher Education Research Edition) 108:108-110.

[8] Zang N. 2012. Volunteer Service: Spiritual Value and Innovation Practice. Guangming Daily [N] 04-15:007.

[9] Gao S. 2014. Taking the Socialist Core Values to Guide College Students' Volunteer Service [J]. Journal of the National Academy of Education Administration 12: 10-14.

[10] Cai Z. C. 2017. Evaluation of Long-term Mechanism of Young College Students' Volunteer Service [J]. School Party Building and Ideological Education 46: 46-47. 